\title{
PEMBERDAYAAN MASYARAKAT SEKITAR HUTAN PADA PROGRAM HUTAN KEMASYARAKATAN DI KABUPATEN SANGGAU
}

\author{
Emi Roslinda ${ }^{1 *}$, Reni Rianty ${ }^{2}$, \& Herculana Ersinta ${ }^{3}$ \\ ${ }^{1}$ Fakultas Kehutanan, Universitas Tanjungpura, Pontianak, 78112 \\ ${ }^{2}$ Badan Penelitian dan Pengembangan Provinsi Kalimantan Barat, \\ Pontianak, 78121 \\ ${ }^{3}$ Yayasan Dian Tama, Pontianak, 78124
}

Email korespondensi : eroslinda71@gmail.com

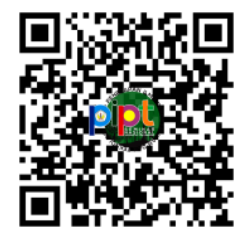

10.26418/pipt.2021.27

\begin{abstract}
Abstrak
Pemberdayaan masyarakat merupakan bagian yang tak terpisahkan dengan program Hutan Kemasyarakatan yang memberikan hak akses kepada masyarakat desa sekitar hutan dalam mengelola hutan negara. Tujuan penelitian ini menjelaskan kegiatan pemberdayaan masyarakat yang sudah dilakukan di beberapa izin HKm yang ada di Kabupaten Sanggau serta mengetahui penilaian masyarakat terhadap program pemberdayaan yang telah dilakukan. Penelitian dilakukan dengan metode survey, penentuan responden dan informan kunci dilakukan secara purposive sampling terhadap anggota IUPHKm dan tokoh-tokoh yang terlibat dalam kegiatan pemberdayaan masyarakat di lokasi penelitian. Pengumpulan data dilakukan dengan penyebaran angket, wawancara mendalam serta observasi. Analisa data dilakukan secara deskriptif kuantitatif dan kualitatif. Program pemberdayaan masyarakat yang dilakukan pada kawasan HKm di Kabupaten Sanggau difasilitasi oleh pihak Pemerintah (Nasional, Provinsi, Kabupaten, Kecamatan dan Desa) dan lembaga Swadaya Masyarakat yang bertujuan meningkatkan kapasitas masyarakat dalam memanfaatkan dan mengelola sumberdaya hutan dan meningkatkan perekonomian serta kesejahteraan masyarakat dari sumberdaya hutan. Bentuk pemberdayaan lebih kepada fasilitasi untuk pembentukan usaha berdasarkan potensi sumberdaya alam yang ada. Masyarakat menilai baik kegiatan pemberdayaan yang sudah dilakukan, tapi masih terus memerlukan pendampingan untuk keberlanjutan kegiatannya.
\end{abstract}

Kata kunci: pemberdayaan, hutan kemasyarakatan, sumberdaya hutan, usaha, perekonomian

\section{PENDAHULUAN}

Hutan merupakan ekosistem yang mengandung kelimpahan sumber daya flora, fauna maupun jasa lingkungan lainnya. Kekayaan yang dimilikinya sesungguhnya menjadi salah satu tumpuan hidup untuk mendukung kesejahteraan masyarakat di sekitar hutan. Namun kenyataannya kemiskinan, pengangguran dan ketimpangan pendapatan justru terjadi di desa-desa sekitar hutan. Forclime (2015) menjelaskan bahwa penyebab utama stagnasi dan kemunduran kehidupan ekonomi masyarakat di daerah pedesaan adalah ketidakadilan dalam hak pengelolaan dan pemanfaatan sumber daya hutan atau akses masyarakat terhadap sumberdaya hutan yang terbatas yang ada selama beberapa dekade ini.
Dengan demikian perlu adanya perlakuan tersendiri untuk melindungi kehidupan masyarakat sekitar hutan dan memberikan penyuluhan, bimbingan serta pendampingan dalam proses pemberdayaan masyarakat.

Pemberdayaan masyarakat adalah konsep pembangunan ekonomi yang merangkum nilainilai masyarakat untuk membangun paradigma baru dalam pembangunan yang bersifat peoplecentered, participatory, empowerment dan sustainable (Chamber, 1995). Lebih lajut dinyatakan pembangunan dengan model pemberdayaan masyarakat adalah upaya mencari alternatif pertumbuhan ekonomi lokal, bukan hanya untuk memenuhi kebutuhan dasar (basic need).

Perubahan paradigma pembangunan kehutanan melahirkan kebijakan Perhutanan Sosial(PS) tentunya selalu akan terpaut dengan proses pemberdayaan masyarakat (empowerment) di sekitar hutan sebagai strategi 
alternatifnya. Pemerintah Daerah Provinsi Kalimantan Barat dalam RPJMD Provinsi Kalimantan Barat 2018-2023 memiliki mandat untuk mengupayakan perekonomian masyarakat desa di sekitar hutan melalui strategi peningkatan kualitas penyelenggaraan penyuluhan kehutanan dan pemberdayaan masyarakat sekitar hutan. Kebijakan diarahkan dengan cara pemberian akses pengelolaan sumber daya hutan yang berkerakyatan dan berkeadilan melalui pengembangan PS. Keberadaan PS diharapkan dapat mendukung pembangunan berkelanjutan dimana aspek sosial, ekonomi, dan ekologi menjadi kekuatan yang saling mengisi dan menjaga potensi serta kemampuan desa untuk mensejahterakan kehidupan desa terutama pada desa-desa di sekitar hutan.

Hutan Kemasyarakatan (HKm) di Kabupaten Sanggau yang saat ini di bawah pengelolaan Kesatuan Pengelolaan Hutan (KPH) Sanggau Timur merupakan salah satu model PS yang memberikan hak akses pengelolaan hutan kepada masyarakat. Selain itu pemberian izin pengelolaan diharapkan dapat meningkatkan kapasitas pengelolanya serta meningkatkan perekonomian masyarakat. Pada pemberdayaan masyarakat di sekitar hutan, maka Häyrinen dkk. (2016) dan Ming'ate dkk. (2014) dalam Golar dkk. (2017) menjelaskan bahwa peningkatan akses masyarakat melalui skema-skema pemberdayaan menjadi hal yang penting untuk diperhatikan. Melalui pemberian akses maka peluang peningkatan kesejahteraan masyarakat akan semakin besar. Program-program pemberdayaan masyarakat, baik yang diprakarsai pemerintah maupun pihak donor yang ada diharapkan mampu untuk menjadi jembatan di dalam menyeimbangkan laju pembangunan dan pengentasan masalah kemiskinan. Penelitian ini bertujuan menguraikan kegiatan pemberdayaan masyarakat yang sudah dilakukan di beberapa izin $\mathrm{HKm}$ yang ada di
Kabupaten Sanggau serta mengetahui penilaian masyarakat terhadap program pemberdayaan yang telah dilakukan.

\section{METODOLOGI}

Penelitian dilaksanakan pada area/kawasan yang telah mendapatkan izin HKm yang berada di Kabupaten Sanggau (8.475 Ha, 10 unit) Provinsi Kalimantan Barat pada bulan September-November 2020. Lokasi HKm yang diteliti berada di Kecamatan Jangkang, Kembayan dan Noyan pada 10 Izin Usaha Pengelolaan Hutan Kemasyarakatan (IUPHKm).

Penelitian dilakukan dengan metode survey. Pengambilan sampel masyarakat dilakukan secara purposive sampling, yaitu masyarakat yang menjadi anggota $\mathrm{HKm}$ untuk melakukan penilaian terhadap program pemberdayaan di lokasi HKm yang pengumpulan datanya dilakukan dengan pengisian kuesioner. Wawancara mendalam dilakukan kepada para informan kunci, yaitu perwakilan pemerintah provinsi, kabupaten, kecamatan dan desa, pihak Lembaga Swadaya Masyarakat, sektor swasta, dan tokoh-tokoh masyarakat (kepala adat, tumenggung) yang terlibat dan mengetahui kegiatan pemberdayaan masyarakat yang telah dilakukan di lokus penelitian.

Pada pengumpulan informasi terkait bentuk penerapan PS dan pemberdayaan masyarakat yang sudah/sedang dilakukan, informasi didapatkan dari persepsi masyarakat dan stakeholders yang dikumpulkan melalui diskusi terfokus dan pengisian angket/kuesioner. Data yang diinventarisasi data-data sebagai berikut sebagaimana meliputi aspek-aspek Martina (2016), yaitu:

1. Sumber daya Manusia, meliputi: kapasitas individu; kapasitas entitas/kelembagaan; kapasitas sistem jejaring

2. Peningkatan terhadap Usaha Masyarakat, mencakup: Pemilihan komoditas dan jenis usaha; Studi kelayakan dan perencanaan bisnis; Pembentukan badan usaha; Perencanaan investasi dan penetapan sumber-sumber pembiayaan; Pengelolaan SDM dan pengembangan karir; ada 
tidaknya dan tetap atau tidaknya Lembaga keuangan dan pasar produk

3. Pengetahuan dan Persepsi terhadap lingkungan, antara lain: Manfaat lingkungan SDAH; Keberadaan konflik sosial; Keberadaan konflik tanah/lahan; Keberadaan illegal logging dan kriminalitas lainnya; Keberadaan bencana alam,

4. Kejelasan dan konsistensi managerial kelembagaan, pada empat komponen: Komponen person; Komponen kepentingan; Komponen aturan; Komponen organisasi/kelembagaan

5. Dukungan Pendampingan dari Stakeholders, misalnya: Peranan instansi pemangku pendampingan Perhutanan Sosial, baik sebagai eksekutor (implementator) maupun katalisator (pendamping); Peranan Pendamping non instansi pemerintah (ada tidaknya pendamping, intensif/tidak kegiatan pendampingan, kompetensi pendamping); Peranan Pemerintah Desa; Peranan Perguruan Tinggi

Analisa data mengacu pada kriteria dan indikator pada penerapan perhutanan sosial dan program pemberdayaan yang telah disusun. Pengukuran menggunakan metode skoring dengan skala 0-3, untuk mengidentifikasi persepsi responden terhadap informasi/ pernyataan. Untuk pernyataan positif yang meliputi 4 pilihan yaitu Setuju (3), Ragu-Ragu (2), Tidak Setuju (1) dan Tidak Tahu (0). Sedangkan untuk pernyataan negatif, skoring penilaian berkebalikan dari pernyataan positif, yaitu, Setuju (1), Ragu-Ragu (2), Tidak Setuju (3) dan Tidak Tahu (0). Hasil perolehan skoring selanjutnya diklasifikasi dalam 5 kategori, penerapan PS yaitu: Sangat tinggi, tinggi, sedang, rendah dan sangat rendah.

\section{HASIL DAN PEMBAHASAN}

\section{Kegiatan Pemberdayaan Masyarakat Di Hutan Kemasyarakatan Kabupaten Sanggau}

Program PS merupakan bagian dari pembangunan desa yang bertujuan untuk meningkatkan kesejahteraan masyarakat desa dan kualitas hidup manusia, serta penanggulangan kemiskinan melalui pemenuhan kebutuhan dasar, pembangunan sarana dan prasarana desa, pengembangan potensi ekonomi lokal, serta pemanfaatan sumber daya alam dan lingkungan secara berkelanjutan (Pasal 78 Ayat 1 UU Nomor 6 Tahun 2014 tentang Desa).

Peraturan Menteri LHK Nomor 83 Tahun 2016 tentang Perhutanan Sosial Pasal 61 Ayat 1 sampai dengan 3 menjelaskan bahwa Pemerintah dan Pemerintah Daerah memfasilitasi pemegang HPHD, IUPHKm, IUPHHK-HTR, Kemitraan Kehutanan dan Pemangku Hutan Adat. Fasilitasi yang diberikan meliputi fasilitasi pada tahap usulan permohonan, penguatan kelembagaan, peningkatan kapasitas termasuk manajemen usaha, pembentukan koperasi, tata batas, area kerja, penyusunan rencana pengelolaan hutan, rencana kerja usaha, dan rencana kerja tahunan, bentuk-bentuk kegiatan kemitraan kehutanan, pembiayaan, pasca panen, pengembangan usaha dan akses pasar.

Disampaikan oleh KPH Sanggau Timur bahwa beberapa pendampingan yang pernah diberikan kepada masyarakat selama pengelolaan hutan di bawah KPH sejak tahun 2019, antara lain:

1. Fasililitasi legalitas kelompok usaha,

2. Pendampingan tentang pengolahan hasil hutan menjadi industri kreatif,

3. Mengikuti berbagai event promosi berupa pameran di tingkat local, kabupaten, provinsi maupun nasional seperti di Gawai Dayak, Peran ICRA, pameran INACRAFT, Pekan Raya Nusantara, dan lain-lain,

4. Fasilitasi pemasaran produk di Griya Kerajinan Dewan Kerajinan Nasional Daerah (DEKRANASDA) Kabupaten Sanggau,

5. Pelatihan / bimbingan teknis melalui Dinas Perindagkop dan Dekranasda Kabupaten Sanggau, 
6. Fasilitasi pinjaman modal bagi UKM,

7. Bantuan mesin dan peralatan kerja

Sebelumnya, melalui Kerjasama pada program KLHK-ITTO (2015-2017), bersama Pemerintah Desa Mobui dan Dinas Pariwisata, pernah dilakukan pendampingan berupa :

1. Pembentukan kelompok sadar wisata dengan SK Kades Mobui,

2. Studi banding ke Bali dan Lombok,

3. Fasilitasi Desa Mobui sebagai Desa Wisata Kabupaten Sanggau,

4. Fasilitasi penyusunan kesepakatan adat dalam pengelolaan Riam Jito Komplek

(ITTO dan KLHK, 2018).

Selain itu, pada tahun 2020, KPH Sanggau Timur juga telah mencoba memberikan penyuluhan kepada masyarakat tentang teknologi sederhana tepat guna dalam rangka menanggulangi kebakaran lahan melalui pemanfaatan kayu tebangan menjadi produk cuka kayu (smoke liquid) dengan teknik destilasi. Cuka kayu tersebut dapat menjadi unggulan untuk membantu mempercepat proses koagulasi hasil okulasi getah/karet bakwan hasil sadap masyarakat. Produk ini mendapat respon positif dari masyarakat. Masyarakat memiliki alternatif untuk mempercepat penggumpalan karet sehingga waktu mereka untuk menyadap karet akan lebih optimal.

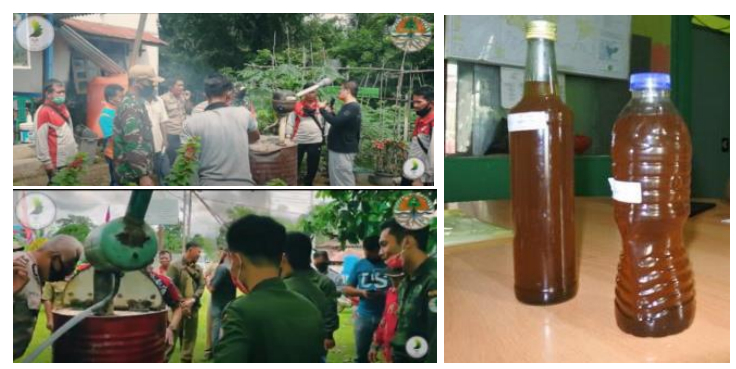

Source: (doc. KPH Sanggau Timur, 2020 dan Tim Peneliti, 2020)

Gambar 1. Penyuluhan Teknologi Cuka Kayu Oleh KPH Sanggau Timur

Kegiatan pemberdayaan yang sudah dilakukan umumnya digagas oleh pihak luar yang melakukan kegiatan pemberdayaan. Ide-ide pemberdayaan belum dilakukan secara bottom up sesuai kebutuhan masyarakat, tapi berdasarkan program/kegiatan dari penggerak pemberdayaan. Karena pemberdayaan masyarakat menjadi concern publik dan dinilai sebagai salah satu pendekatan yang sesuai dalam mengatasi berbagai masalah sosial, yang dilaksanakan berbagai elemen mulai dari pemerintah, dunia usaha dan masyarakat melalui organisasi masyarakat sipil (Widayanti 2012).

Walaupun belum sepenuhnya bersifat bottom up, tetapi kegiatan-kegiatan yang dilakukan telah menyesuaikan dengan potensi alam yang ada, sehingga telah memberi pengetahuan baru bagi masyarakat untuk mengolah sumberdaya alam yang ada di sekitar tempat tinggal mereka. Ini menunjukkan adanya penambahan pengetahuan dan wawasan yang lebih luas bagi masyarakat, berarti terjadi peningkatan kapasitas masyarakat baik secara individu maupun kelompok. Hal ini sejalan dengan konsep dari pemberdayaan Robbins, Chatterjee, dan Canda (dalam Ramos dan Prideaux, 2014) yang mengemukakan bahwa pemberdayaan adalah proses yang menggambarkan sarana dimana individu dan kelompok memperoleh kekuasaan, akses ke sumberdaya dan keuntungan kontrol atas hidup mereka.

\section{Penilaian Masyarakat Tentang Program Perhutanan Sosial dan Pemberdayaan Masyarakat}

Perhutanan sosial merupakan wujud keberpihakan negara pada konsep pembangunan hutan yang diharapkan dapat mengakomodir kebutuhan dan kesejahteraan masyarakat di sekitar hutan (Nandini, 2013). Melalui kebijakan ini, beberapa hal yang dikehendaki oleh Pemerintah yaitu:

1. Menciptakan dan mempercepat pemerataan akses distribusi aset sumber daya hutan;

2. Menyelesaikan konflik tenurial di Kawasan hutan; dan

3. Mengurangi kemiskinan dan meningkatkan kesejahteraan masyarakat yang tertinggal di dalam dan di sekitar Kawasan hutan. 
Berdasarkan hasil pengisian angket, sebagaimana yang ditampilkan pada tabel berikut, masyarakat menilai bahwa program PS dengan skema HKm memiliki potensi penerapan yang sangat tinggi/sangat baik.

Tabel 1. Penilaian Masyarakat Tentang Program Perhutanan Sosial

\begin{tabular}{|c|c|c|c|c|c|c|c|c|c|}
\hline \multirow{3}{*}{ isictele } & \multirow{3}{*}{$\begin{array}{l}\text { Pengubar } \\
\text { is ismot }\end{array}$} & \multicolumn{4}{|c|}{ 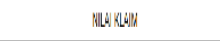 } & \multicolumn{4}{|c|}{ 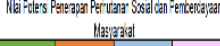 } \\
\hline & & 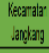 & 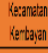 & $\begin{array}{r}\text { Ketemantas } \\
\text { Hopan } \\
\end{array}$ & 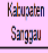 & Keamazan & Keerasar & Kasaralan & (abtraler \\
\hline & & 4 & 34 & 42 & 116 & & & & \\
\hline  & 21 & \multirow{4}{*}{2166} & \multirow{4}{*}{1911} & \multirow{4}{*}{231} & \multirow{4}{*}{ S|l| } & \multirow{4}{*}{$\begin{array}{l}\text { SHFW } \\
\text { TKGGO }\end{array}$} & \multirow{4}{*}{$\begin{array}{l}\text { SWMGT } \\
\text { TI:GES }\end{array}$} & \multirow{4}{*}{$\begin{array}{l}\text { SH,GGT } \\
\text { THKGO }\end{array}$} & \multirow{4}{*}{$\begin{array}{l}\text { SWIGA } \\
\text { THGOA }\end{array}$} \\
\hline Kisterbazan & & & & & & & & & \\
\hline Kenanglatar & & & & & & & & & \\
\hline 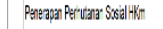 & & & & & & & & & \\
\hline
\end{tabular}

Masyarakat pemilik IUPHKm menyebutkan bahwa pada aspek kelembagaan, IUPHKm disahkan oleh Bupati (Pemilik 5 unit IUPHKm, dengan penetapan tahun 2012 dan 2013) ataupun Menteri LHK (pemilik 5 unit IUPHKm, dengan penetapan tahun 2017). Adanya ketetapan yang sah tersebut memberikan makna kepada mereka bahwa berbagai kegiatan yang mereka lakukan di dalam Kawasan Hutan Negara ini, baik bermukim, bersawah/berladang, menoreh/ menyadap dan atau mengambil hasil hutan lainnya untuk memenuhi kebutuhan hidup dasar mereka adalah hal yang tidak melanggar hukum. Salah seorang warga berpendapat "Kami setuju dengan adanya penetapan daerah kami sebagai HKm, ijin ini memberikan kami legalitas, dan membantu kami menjaga kawasan hutan kami sebagai tempat hidup kami dari sawit ataupun perusahaan-perusahaan yang ingin menguasai hutan kami". Namun, keberadaan peraturan tersebut tidak berimplikasi terlalu besar terhadap aktifitas mereka sehari-hari. Salah seorang warga menyebutkan "sebelum ataupun sesudah ada aturan tentang HKm ini aktifitas sehari-hari kami ya dari dulu dan sekarang pun tetap begini, rumah kami di sini, cari makan juga di sini”. Para Penyuluh dan Pendamping PS menyampaikan bahwa sebagaimana kebijakan yang berlaku, adanya program PS skema HKm adalah memberikan legalitas atau kepastian hukum kepada masyarakat untuk dapat mengakses dan memanfaatkan kawasan hutan negara (baik hutan lindung maupun hutan produksi) untuk membantu meningkatkan kesejahteraan mereka. Legalitas tersebut didapatkan melalui pengusulan kelompok masyarakat yang selanjutnya disahkan melalui keputusan Bupati (dahulu) ataupun dengan keputusan Menteri atau Gubernur (saat ini).

Pada pengusulan $\mathrm{HKm}$, telah dilengkapi dengan persyaratan berupa jumlah anggota, struktur dasar organisasi (seperti ketua, sekretaris, bendahara, dan lain sebagainya). Organisasi HKm diselenggarakan dalam bentuk Kelompok Tani (Poktan) maupun Gabungan Kelompok Tani (Gapoktan). Dalam pengusulan, organisasi mereka telah memiliki rencana kerja dan jenis usaha perhutanan sosial (UPS) yang akan dilaksanakan. Oleh karena itu, ketika dikonfirmasi kepada masyarakat terkait permasalahan keberadaan ketetapan yang sah maupun struktur organisasi dan uraian tugas yang jelas, masyarakat mengakui hal-hal tersebut telah terpenuhi di kelompok IUPHKm mereka.

Pada kelompok HKm memiliki aturan bersama yang telah disepakati pada awal pengusulan $\mathrm{HKm}$. Kesepakatan meliputi kepengurusan organisasi $\mathrm{HKm}$, tata cara pengelolaan $\mathrm{HKm}$, data potensi hasil hutan dan rencana kegiatan usaha perhutanan sosial (UPS). Organisasi juga dilengkapi dengan Anggaran Dasar dan Anggaran rumah Tangga. Namun, realisasi misalnya tentang pertemuan rutin/regular anggota masih belum berjalan optimal. Salah satu pengurus kelompok IUPHKm menjelaskan "sampai dengan saat ini, kategori rutinnya rapat kalau ada kunjungan pendamping. Karena terus terang kami masih bingung, terkait pembahasan apa yang perlu dirapatkan, terus bagaimana pendanaan rapatnya." Hal ini mengindikasikan bahwa 
kemampuan masyarakat terkait fungsi kelompok $\mathrm{HKm}$ dan bagaimana menerapkan

pengorganisasian/pengelolaan kelompok belum dipahami. Secara langsung, hal ini memberikan efek terhadap rencana pemanfaatan hasil hutan sebagai KUPS pun belum mampu mereka koordinir secara bersama-sama sebagai usaha perhutanan sosial. Disebutkan pada pertemuan pengumpulan informasi, warga menyampaikan bahwa: "yang kami tahu, secara hukum negara telah mengakui masyarakat untuk mengambil hasil hutan, tetapi untuk kegiatannya sendiri dengan adanya HKm masih belum ada. Usaha-usaha yang disebutkan dalam UPS semuanya masih sendiri-sendiri karena hasilnya pun memang dari petakan kami sendiri."

Penilaian masyarakat terhadap keanggotaan $\mathrm{HKm}$, disampaikan bahwa keanggotaan setiap $\mathrm{HKm}$ di masingmasing IUPHKm telah diakui secara de jure, karena nama-nama anggota $\mathrm{HKm}$ terlampir di dalam SK Penetapan IUPHKm.yang ditandatangani oleh Bupati/Gubernur/Menteri. Masyarakat yang terlibat adalah berdasarkan Kartu Keluarga, yang tergabung ke dalam kelompok tani (Poktan) ataupun gabungan kelompok (Gapoktan). Sifat keanggotaan tetap untuk masa 35 tahun sesuai dengan masa ijin $\mathrm{HKm}$. Kepengurusan dapat berganti 3 atau 5 tahun sekali sebagaimana yang diatur dalam AD/ART masing-masing Kelompok IUPHKm. Namun, dari hasil wawancara disampaikan bahwa anggota kelompok HKm cenderung enggan untuk terlibat kepengurusan. Anggota HKm masih berfikir bahwa keterlibatan mereka dalam kepengurusan akan menambah beban atau tanggung jawab mereka. Mereka pun cenderung tidak tahu harus berbuat apa dan keuntungan apa saja yang akan mereka dapatkan jika terlibat dalam kepengurusan di kelompok IUPHKm.
Meskipun sampai dengan saat ini tidak terdapat sengketa/konflik terkait pemanfaatan lahan di setiap tempat yang ber-IUPHKm, namun masyarakat berpendapat bahwa terdaftarnya mereka sebagai anggota $\mathrm{HKm}$ adalah menjadi legalitas kaplingan/petakan yang mereka kelola di Kawasan hutan, sehingga jika terdapat masalah (konflik/sengketa) dengan pihak lain, masyarakat dapat mempertahankan hak mereka atas tanah kelola di kawasan hutan negara tersebut. Hak-hak mereka untuk dapat memanfaatkan hasil hutan dan atau kewajiban mereka untuk memanfaatkan hasil hutan dengan cara yang bijaksana untuk mendukung kehidupan mereka sehari-hari telah dipahami masyarakat sepenuhnya. Kondisi ini akan mendukung keterlibatan dan peran serta masyarakat untuk dapat melakukan kegiatan berbasis sumberdaya (Roslinda dkk. 2020)

Oleh karena itu, sosialisasi keberadaan kawasan hutan negara, serta adanya kebijakan perhutanan sosial dinilai telah berjalan dengan tepat. Masyarakat telah menyadari untuk pemanfaatan jasa lingkungan dan HHBK di hutan lindung, dan pemanfaatan HHBK, jasa lingkungan dan HHK dalam jumlah yang terkontrol di hutan produksi. Namun, keberadaan kebijakan Perhutanan sosial ini masih harus ditindaklanjuti dengan penyelenggaraan penyuluhan kehutanan dan pemberdayaan masyarakat sekitar hutan agar masyarakat tidak hanya mendapatkan hasil hutan untuk pemenuhan kebutuhan dasar harian mereka saja tetapi juga dapat meningkatkan kapasitas dan kemandirian masyarakat untuk mewujudkan kesejahteraannya.

Masyarakat menilai bahwa program HKm telah disertai dengan pemberdayaan masyarakat. Masyarakat dilibatkan dalam penyusunan potensi RKUPS (Rencana Kerja Usaha Perhutanan Sosial) dan RKT (Rencana Kerja Tahunan) ketika mengusulkan penetapan IUPHKm. Namun, masyarakat masih membutuhkan dalam mengisi keberlangsungan IUPHKm. Beberapa pelatihan dan bimbingan teknis telah dilaksanakan oleh pemerintah melalui instansi-instansi teknis tertentu yang melibatkan perwakilan masyarakat anggota $\mathrm{HKm}$, namun perwakilan masyarakat tersebut 
merasa belum menjadi sebuah kewajiban bagi dirinya untuk mentransfer informasi atau pengetahuan atau keterampilan yang didapatkannya tersebut kepada anggota lainnya sehingga informasi yang didapat, hanya sebatas untuk diri sendiri. Selanjutnya, pengetahuan/keterampilan tersebut, umumnya tidak diaplikasikan dalam kehidupan sehari-hari sehingga tidak menumbuhkembangkan pengetahuan maupun potensi kreatifitas yang ada. Mereka menyampaikan, misalnya pada pelatihan kerajinan/anyaman, terkadang bimbingan/pelatihan diberikan kepada orang-orang itu saja, atau tidak sesuai dengan kebutuhan mereka. Ketiadaan informasi pasar akan mereka hadapi ketika mereka telah menghasilkan produk adalah menjadi salah satu stagnannya masyarakat pasca bimbingan/penyuluhan.

Ini menunjukkan pemberdayaan masyarakat tidak hanya untuk penguatan individu tetapi juga penguatan pranatapranata dan kelembagaan sosial yang mendukungnya. Menanamkan rasa ingin berbagi, keterbukaan, bekerja sama, bekerja keras, bertanggung jawab merupakan bagian penting untuk mendukung keberhasilan usaha pemberdayaan masyarakat. Seperti yang disampaikan oleh Noor (2011), bahwa enabling, empowering dan protecting menjadi pilar utama pemberdayaan masyarakat sebagai model pembangunan yang berbasis rakyat.

\section{KESIMPULAN}

Program pemberdayaan masyarakat yang dilakukan pada kawasan Hutan Kemasyarakatan di Kabupaten Sanggau difasilitasi oleh pihak Pemerintah (Nasional, Provinsi, Kabupaten, Kecamatan dan Desa) dan lembaga Swadaya Masyarakat yang bertujuan meningkatkan kapasitas masyarakat dalam memanfaatkan dan mengelola sumberdaya hutan dan meningkatkan perekonomian serta kesejahteraan masyarakat dari sumberdaya hutan. Bentuk pemberdayaan diarahkan pada penguatan usaha masyarakat dalam memanfaatkan sumberdaya dan potensi hutan yang ada. Masyarakat dapat mengembangkan kapasitasnya ketika sudah mendapatkan akses dan kontrol terhadap sumberdaya yang ada dan memperoleh manfaat dari sumberdaya tersebut. Peningkatan kapasitas masyarakat secara individu perlu didukung dengan kelembagaan sosial yang kuat pula untuk mendukung program pemberdayaan masyarakat dapat mencapai tujuannya.

\section{UCAPAN TERIMA KASIH}

Terima kasih disampaikan kepada Badan Litbang Provinsi Kaimantan Barat yang telah mendanai penelitian ini pada tahun anggaran 2020, dan kepada KPH Sanggau Timur serta masyarakat anggota $\mathrm{HKm}$ di Kabupaten Sanggau yang sudah menjadi narasumber dalam penelitian ini.

\section{DAFTAR PUSTAKA}

Chambers, R (1995). Pembangunan Desa Mulai dari Belakang. Yogyakarta: LP3ES.

Forests and Climate Change Programme (FORCLIME) (2015). Module Lembar Singkat No. 6: April 2015, akses : www.forclime.org > Briefing Note > Bahasa

Golar, Muis H, Ali MN. (2017). Efektivitas Pemberdayaan Masyarakat Wilayah Hutan Lindung: Penerapan Skema Perhutanan Sosial di Desa Namo, Journal of Environmental Management 16 (1): $51-59$

ITTO dan KLHK. 2018. Project Completion Report ITTO Project TFL-PD32/13.Rev 2.(M): Strengthening the Capacity of Local Institutions to Sustainably Manage Community Forestry in Sanggau for Improving Livelihood. Kementerian Lingkungan Hidup dan Kehutanan. Bogor. 
Martina. (2016). Lingkup dan Tahapan Kegiatan Pemberdayaan Masyarakat (ppt), Prodi Agribisnis Fak PErtanian Univ Malikussaleh, akses: http://repository.unimal.ac.id/115 6/1/Tahapan\%20Keg.\%20Pember dayaan\%20Masyarakat.pdf

Nandini R. (2013). Evaluasi Pengelolaan Hutan Kemasyarakatan (HKm) Pada Hutan Produksi dan Hutan Lindung di Pulau Lombok. Jurnal Penelitian Hutan Tanaman 10(1): 43-55

Noor M. (2011). Pemberdayaan Masyarakat, Civis 1(2): 87-99

Ramos AM \& Prideaux B. (2014). Indigenous Ecotourism in The Mayan Rainforest of Palenque:
Empowerment Issues in Sustainable Development, Journal of Sustainable Tourism, 22(3): 461-479

Roslinda E, Listiyawati L, Ayyub, Fikri FA (2020). The Involvement of Local Community in Mangrove Forest Conservation in West Kalimantan, Jurnal Sylva Lestari 9(2): 291-301

Wibawa A. (2014). Pemberdayaan Masyarakat dalam Rehabilitasi Hutan Lahan melalui Program Kebun Bibit rakyat di desa Sumberrejo Kecamatan Tempel Kabupaten Sleman, Jurnal Pembangunan Wilayah dan Kota, 10(2): 187-196

Widayanti. (2012). Pemberdayaan Masyarakat: Pendekatan Teoritis, Jurnal Welfare, 1(1): 87-102 